\title{
Vertical characterization of aerosol optical properties and brown carbon in winter in urban Beijing, China
}

\author{
Conghui Xie ${ }^{1,2}$, Weiqi Xu ${ }^{1,2}$, Junfeng Wang ${ }^{4}$, Qingqing Wang ${ }^{1}$, Dantong Liu ${ }^{5}$, Guiqian Tang ${ }^{1}$, Ping Chen ${ }^{6}$, Wei Du ${ }^{1,2}$, \\ Jian Zhao ${ }^{1,2}$, Yingjie Zhang ${ }^{1}$, Wei Zhou ${ }^{1,2}$, Tingting Han ${ }^{1}$, Qingyun Bian ${ }^{2,7}$, Jie $\mathbf{L i}^{1}$, Pingqing Fu ${ }^{1,2}$, Zifa Wang ${ }^{1,2,3}$, \\ Xinlei Ge ${ }^{4}$, James Allan ${ }^{5,8}$, Hugh $\mathrm{Coe}^{5}$, and Yele Sun ${ }^{1,2,3}$ \\ ${ }^{1}$ State Key Laboratory of Atmospheric Boundary Layer Physics and Atmospheric Chemistry, Institute of Atmospheric \\ Physics, Chinese Academy of Sciences, Beijing 100029, China \\ ${ }^{2}$ College of Earth Sciences, University of Chinese Academy of Sciences, Beijing 100049, China \\ ${ }^{3}$ Center for Excellence in Regional Atmospheric Environment, Institute of Urban Environment, Chinese Academy \\ of Sciences, Xiamen 361021, China \\ ${ }^{4}$ School of Environmental Science and Engineering, Nanjing University of Information Science \& Technology, \\ Nanjing 210044, China \\ ${ }^{5}$ Centre for Atmospheric Science, School of Earth, Atmospheric and Environmental Science, University of Manchester, \\ Manchester M13 9PL, UK \\ ${ }^{6}$ Handix Scientific LLC, Boulder, CO 80301, USA \\ ${ }^{7}$ CAS Key Laboratory of Regional Climate-Environment Research for Temperate East Asia, Institute of Atmospheric Physics, \\ Chinese Academy of Sciences, Beijing 100029, China \\ ${ }^{8}$ National Centre for Atmospheric Science, The University of Manchester, Manchester, UK
}

Correspondence: Yele Sun (sunyele@ mail.iap.ac.cn)

Received: 31 July 2018 - Discussion started: 17 August 2018

Revised: 29 November 2018 - Accepted: 29 November 2018 - Published: 4 January 2019

\begin{abstract}
Aerosol particles are of importance in the Earth's radiation budget since they scatter and absorb sunlight. While extensive studies of aerosol optical properties have been conducted at ground sites, vertical measurements and characterization are very limited in megacities. In this work, we present simultaneous real-time online measurements of aerosol optical properties at ground level and at $260 \mathrm{~m}$ on a meteorological tower from 16 November to 13 December in 2016 in Beijing along with measurements of continuous vertical profiles during two haze episodes. The average $( \pm 1 \sigma)$ scattering and absorption coefficients $\left(b_{\text {sca }}\right.$ and $\left.b_{\text {abs }} ; \lambda=630 \mathrm{~nm}\right)$ were $337.6( \pm 356.0)$ and $36.6( \pm 33.9) \mathrm{Mm}^{-1}$ at $260 \mathrm{~m}$, which were $26.5 \%$ and $22.5 \%$ lower than those at ground level. Single scattering albedo (SSA), however, was comparable between the two heights, with slightly higher values at ground level $(0.89 \pm 0.04)$. Although $b_{\text {sca }}$ and $b_{\text {abs }}$ showed overall similar temporal variations between ground level and $260 \mathrm{~m}$, the ratios of $260 \mathrm{~m}$ to ground varied substantially from less than 0.4 during the clean stages of haze episodes
\end{abstract}

to $>0.8$ in the late afternoon. A more detailed analysis indicates that vertical profiles of $b_{\text {sca }}, b_{\mathrm{abs}}$, and SSA in the low atmosphere were closely related to the changes in meteorological conditions and mixing layer height. The mass absorption cross section (MAC) of equivalent black carbon (eBC, $\lambda=630 \mathrm{~nm}$ ) varied substantially from 9.5 to $13.2 \mathrm{~m}^{2} \mathrm{~g}^{-1}$ in winter in Beijing, and it was strongly associated with the mass ratio of coating materials on refractory $\mathrm{BC}(\mathrm{rBC})$ to $\operatorname{rBC}\left(M_{\mathrm{R}}\right)$, and also the oxidation degree of organics in $\mathrm{rBC}$ containing particles. Our results show that the increases in MAC of $\mathrm{eBC}$ in winter were mainly caused by photochemically produced secondary materials. Light absorption of organic carbon (brown carbon, $\mathrm{BrC}$ ) was also important in winter, which on average accounted for $46( \pm 8.5) \%$ and 48 $( \pm 9.3) \%$ of the total absorption at $370 \mathrm{~nm}$ at ground level and $260 \mathrm{~m}$, respectively. A linear regression model combined with positive matrix factorization analysis was used to show that coal combustion was the dominant source contribution of $\mathrm{BrC}(48 \%-55 \%)$ followed by biomass burning (17\%) 
and photochemically processed secondary organic aerosol $(\sim 20 \%)$ in winter in Beijing.

\section{Introduction}

Light scattering and absorption of aerosols reduce visibility and affect the radiation and energy budget of the Earth (Rosenfeld, 1999; Kim and Ramanathan, 2008). Scattering aerosols cool the atmosphere and exert a negative forcing while light-absorbing materials warm the atmosphere and, if they exist over a brighter underlying surface, contribute a positive forcing (Haywood and Boucher, 2000). While scattering particles mainly include ammonium sulfate, ammonium nitrate, and a majority of organics (Han et al., 2015), black carbon $(\mathrm{BC})$ and brown carbon $(\mathrm{BrC})$ are the two major light-absorbing matter sources in fine particles (Bond et al., 2013). Although numerous studies have been conducted to investigate aerosol optical properties, accurate quantification of aerosol radiative forcing still remains challenging (Stocker et al., 2013). While the very complex optical properties affected by mixing states are one of the reasons (Peng et al., 2016; Cappa et al., 2012; Liu et al., 2017), our limited understanding of the vertical distributions of optical properties and their relationship to composition and mixing state is also important. For example, a recent study found that BC near the capping inversion is more effective in suppressing planetary boundary layer height and weakening turbulent mixing (Z. Wang et al., 2018; Ding et al., 2016).

Most previous measurements of aerosol particles in urban Beijing are conducted at ground level (Sun et al., 2013, 2014; Tao et al., 2015), which are subject to the influences of local emissions, such as biomass burning, cooking, and traffic (Sun et al., 2014). Until recently, Sun et al. (2015) reported the first simultaneous measurements of $\mathrm{PM}_{1}$ composition at $260 \mathrm{~m}$ and ground level in urban Beijing in winter 2013. Higher nitrate and much lower primary organic aerosol (POA) at $260 \mathrm{~m}$ than at ground level was observed. This result is consistent with the subsequent observations in autumn 2015 (Zhao et al., 2017). The size distributions of aerosol at $260 \mathrm{~m}$ and ground level are also different, especially for Aitken mode particles (Du et al., 2017). Such differences in concentration, composition, and size distributions between $260 \mathrm{~m}$ and ground level may exert a potential influence on aerosol optical properties. However, the vertical distributions of aerosol optical properties are rarely characterized. Q. Wang et al. (2018) conducted the first continuous vertical measurements of particle extinction and $\mathrm{BC}$ from ground level to 200-260 $\mathrm{m}$ during two severe haze episodes in winter. The results showed four distinct types of vertical profiles that were closely linked with boundary layer dynamics. However, this study is limited within a relatively short time, and the real-time measurements of aerosol optical properties at different heights in Beijing is yet to be performed.
Black carbon, as the major light-absorbing matter in atmospheric aerosol (Bond et al., 2013), absorbs visible light strongly with an absorption Angström exponent (AAE) of $\sim 1$ (Horvath, 1997). The light-absorbing ability of BC is affected by the coating materials which may change substantially during the aging process. The enhancement of $\mathrm{BC}$ absorption due to non-BC materials in BC-containing particles is often referred to as lensing effect (Bond et al., 2006). Previous studies found that internally mixed particulate organic matter with $\mathrm{BC}$ could enhance absorption by up to $70 \%$ (Lack et al., 2012), and the absorption enhancement strongly depends on the $\mathrm{BC}$ coating amount and particle mixing state (Liu et al., 2017; S. Liu et al., 2015). Although Peng et al. (2016) found that the BC light absorption enhancement can be significantly increased in polluted urban environment by using a novel environmental chamber approach, the evaluation of such effects through field measurements are still limited in Beijing. In addition to BC, light-absorbing organic carbon $(\mathrm{BrC})$ plays an important role in affecting radiative forcing at ultraviolet wavelengths (Laskin et al., 2015), although its mass absorption cross section (MAC, also known as mass absorption efficiency) is an order of magnitude less than that of BC in the visible wavelength (Yang et al., 2009). The AAE of $\mathrm{BrC}$ is ubiquitously larger than 1 , yet accurate quantification of absorption of $\mathrm{BrC}$ is challenging (Laskin et al., 2015), particularly in a megacity with complex source emissions and processes. For example, recent studies have found that coal combustion is also an important source of $\mathrm{BrC}$ in winter in Beijing in addition to biomass burning aerosol (Sun et al., 2017; Yan et al., 2017).

In this work, we conducted comprehensive measurements of aerosol optical properties including light extinction coefficients $\left(b_{\text {ext }}\right)$, scattering coefficients $\left(b_{\text {sca }}\right)$, and absorption coefficients $\left(b_{\text {abs }}\right)$ at both ground level and $260 \mathrm{~m}$ on a meteorological tower in winter in 2016 along with two continuous vertical measurements of $b_{\text {sca }}$ and $b_{\text {abs }}$ between ground level and $260 \mathrm{~m}$. The measurements of aerosol optical properties from different instruments are compared, and the vertical differences in $b_{\text {sca }}, b_{\text {abs }}$, and single scattering albedo (SSA) are characterized. Also, the evolution of vertical differences in aerosol optical properties and its relationship with meteorological conditions and aerosol composition are illustrated. In addition, the light absorption capability of BC is estimated, and the contribution of $\mathrm{BrC}$ to $b_{\mathrm{abs}}$ at $370 \mathrm{~nm}$ is quantified.

\section{Experimental methods}

\subsection{Sampling site and measurements}

All measurements at ground level and $260 \mathrm{~m}$ were conducted at the tower site of the Institute of Atmospheric Physics, Chinese Academy of Sciences ( $\left.39^{\circ} 58^{\prime} 28^{\prime \prime} \mathrm{N}, 116^{\circ} 22^{\prime} 16^{\prime \prime} \mathrm{E}\right)$ in Beijing from 16 November to 13 December 2016. A detailed description of the sampling site is given in Zhou et al. (2018). 
Table 1 lists a summary of measurements in this study. At the ground site, $b_{\text {ext }}$ and $b_{\text {sca }}(\lambda=630 \mathrm{~nm})$ of dry particles $\left(\mathrm{PM}_{1}\right)$ were measured by a cavity attenuated phase shift single scattering albedo monitor (CAPS PM ssa $_{\text {, Aero- }}$ dyne Research Inc.) (Onasch et al., 2015) that was installed in a room on the rooftop of a two-storey building $(\sim 8 \mathrm{~m})$. Note that the major uncertainty in scattering measurements caused by the truncation effect is less than $2 \%$ (Han et al., 2017). The detailed description of the CAPS PM ssa $_{\text {in }}$ given in Han et al. (2017). In the same room, a seven-wavelength $(370,470,520,590,660,880$, and $950 \mathrm{~nm})$ Aethalometer (AE33, Magee Scientific Corp.) was used to measure BC at a time resolution of $1 \mathrm{~min}$. This version of the Aethalometer uses a compensation algorithm based on "dual-spot" measurements to automatically correct the filter-based loading effects (Drinovec et al., 2015). According to Petzold et al. (2013), BC measured by AE33 was defined as equivalent $\mathrm{BC}(\mathrm{eBC})$ unless otherwise stated. In addition, a photoacoustic extinctiometer (PAX, Droplet Measurement Technologies) was used to measure $b_{\text {sca }}$ and $b_{\text {abs }}(\lambda=870 \mathrm{~nm})$ of dry $\mathrm{PM}_{2.5}$ in a container at ground level $(\sim 3 \mathrm{~m})$. Other collocated measurements at the same ground site include non-refractory submicron $\left(\mathrm{NR}-\mathrm{PM}_{1}\right)$ aerosol species (organics, sulfate, nitrate, ammonium, and chloride) by an Aerodyne high-resolution time-of-flight aerosol mass spectrometer (HR-AMS hereafter) and refractory black carbon (rBC) and $\mathrm{BC}$-containing species by a soot particle aerosol mass spectrometer (SP-AMS) (Wang et al., 2017; Onasch et al., 2012). In this study, the tungsten vaporizer of the SP-AMS was removed; thus, only rBC-containing particles were measured. Positive matrix factorization (PMF) was performed on the high-resolution mass spectra of organic aerosol (OA) of the HR-AMS and the SP-AMS. Six OA factors were identified from HR-AMS measurements including fossil-fuelrelated OA (FFOA) predominantly from coal combustion, cooking OA (COA), biomass burning OA (BBOA), oxidized POA (OPOA), oxygenated OA (OOA), and aqueous-phase OOA (aq-OOA) (Xu et al., 2018). In comparison, four OA factors were identified from SP-AMS measurements including FFOA, BBOA, OOA1, and OOA2. More detailed descriptions of the operations and calibrations of the HR-AMS and SP-AMS, and subsequent PMF analysis can be found in Xu et al. (2015) and Wang et al. (2016).

At $260 \mathrm{~m}$ on the $325 \mathrm{~m}$ Beijing Meteorological Tower (BMT), $b_{\text {ext }}(\lambda=630 \mathrm{~nm})$ of $\mathrm{PM}_{2.5}$ was measured by a cavity attenuated phase shift extinction monitor (CAPS PM ext $_{1}$ Aerodyne Research Inc.), eBC was measured by AE33, and NR-PM 1 aerosol species were measured by an Aerodyne aerosol chemical speciation monitor (ACSM) (Chen et al., 2015).

Continuous vertical measurements from ground level to $240 \mathrm{~m}$ (nighttime) and $260 \mathrm{~m}$ (daytime) were also conducted during 25-26 November and 30 November-4 December 2016. The AE33 and PAX were installed in a small container that was able to travel up and down the BMT. In total,
50 vertical profiles of eBC, $b_{\text {sca }}$, and $b_{\text {abs }}$ were obtained (Table $\mathrm{S} 1$ in the Supplement). The meteorological variables of temperature $(T)$, relative humidity (RH), wind speed (WS), and wind direction (WD) were measured at 15 heights ( 8 , $15,32,47,65,80,100,120,140,160,180,200,240,280$, and $320 \mathrm{~m}$ ) on the BMT. In addition, mixing layer height (MLH) was retrieved from vertical attenuated backscatter coefficients measured by a single-lens ceilometer (CL51, Vaisala, Finland) (Tang et al., 2015, 2016). All data in this study are reported in Beijing local time (UTC $+8 \mathrm{~h})$.

\subsection{Intercomparisons}

Aerosol optical properties and BC measurements from different instruments were evaluated through parallel sampling either before or after the campaign. As shown in Fig. 1b, the 1week intercomparison of the two AE33s shows an excellent agreement in eBC measurements (slope $=1.06, R^{2}=0.94$ ). To be consistent, the eBC measured by $\mathrm{AE} 33_{2}$ was scaled by a factor of 1.06 according to that of AE33 $1 . b_{\text {ext }}$ measured by CAPS PM $\mathrm{Pxt}_{\text {ext }}$ was also highly correlated with that measured by CAPS PM $_{\text {ssa }}\left(R^{2}=0.99\right.$, slope $=1.22$ ) (Fig. 1a). Considering that the CAPS PM $_{\text {ssa }}$ was not calibrated before this campaign, $b_{\text {ext }}$ measured by the CAPS PM $_{\text {ssa }}$ was multiplied by a factor of 1.22 in this study. We also compared the light extinction of $\mathrm{PM}_{1}$ and $\mathrm{PM}_{2.5}$ during the period of intercomparison. As indicated in Fig. 1c, the $b_{\text {ext }}$ of $\mathrm{PM}_{2.5}$ is nearly twice that of $\mathrm{PM}_{1}\left(R^{2}=0.93\right.$, slope $\left.=1.93\right)$, indicating that aerosol particles between 1 and $2.5 \mu \mathrm{m}$ are also important for light extinction in this study. In addition, $b_{\text {sca }}$ measured by CAPS PM ssa $(630 \mathrm{~nm})$ and PAX $(870 \mathrm{~nm})$ is highly correlated $\left(R^{2}=0.98\right)$, and the slope of 2.2 suggests a scattering Ångström efficiency (SAE) of approximately 2.4 (Fig. 1d). Figure 2a shows a comparison of eBC measured by AE33 and SP-AMS for the entire study. It is clear that both independent measurements are highly correlated $\left(R^{2}=0.98\right)$. In our previous study, $b_{\mathrm{abs}}$ of eBC at $630 \mathrm{~nm}$ was derived using a MAC of $7.4 \mathrm{~m}^{2} \mathrm{~g}^{-1}$, i.e., $b_{\mathrm{abs}}=\mathrm{eBC} \times 7.4$ (Han et al., 2017). The eBC-derived $b_{\text {abs }}$ is highly correlated with that from the CAPS PM ssa $_{\text {measurements }}\left(R^{2}=0.89\right.$, slope $=1.01$; Fig. 2b), i.e., $b_{\mathrm{abs}}=b_{\mathrm{ext}}-b_{\mathrm{sca}}$. All these results suggest that $b_{\text {abs }}$ from different measurements agree reasonably well in this study. We then define the MAC of BC at $630 \mathrm{~nm}$ as follows:

$\mathrm{MAC}=b_{\mathrm{abs}} / \mathrm{rBC}$,

where $b_{\mathrm{abs}}$ is the absorption coefficient at $630 \mathrm{~nm}$, and $\mathrm{rBC}$ is the refractory BC from SP-AMS measurements.

\subsection{Calculations of single scattering albedo and brown carbon}

Although single scattering albedo (SSA, $\lambda=630 \mathrm{~nm}$ ) of $\mathrm{PM}_{1}$ can be directly calculated from the CAPS PM $\mathrm{Ssa}_{\mathrm{sa}}$ measurements as $\mathrm{SSA}=b_{\text {sca }} / b_{\text {ext }}$, the SSA of $\mathrm{PM}_{2.5}$ at ground 
Table 1. A summary of measurements in this study.

\begin{tabular}{|c|c|c|c|c|}
\hline & Instruments & Manufacturer & Properties measured & Resolution \\
\hline \multirow[t]{5}{*}{ Ground } & $\begin{array}{l}\text { Cavity attenuated phase shift sin- } \\
\text { gle scattering albedo monitor (CAPS } \\
\mathrm{PM}_{\mathrm{ssa}} \text { ) }\end{array}$ & Aerodyne Research, Inc. & $\mathrm{PM}_{1} b_{\text {ext }}$ and $b_{\text {sca }}(\lambda=630 \mathrm{~nm})$ & $1 \mathrm{~s}$ \\
\hline & Aethalometer $\left(\mathrm{AE} 33_{1}\right)$ & Magee Scientific Corp. & $\begin{array}{l}\text { eBC }(370,470,520,590,660,880 \text {, } \\
\text { and } 950 \mathrm{~nm})\end{array}$ & $1 \mathrm{~min}$ \\
\hline & Photoacoustic extinctiometer (PAX) & droplet measurement technologies & $\mathrm{PM}_{2.5} b_{\mathrm{ext}}$ and $b_{\mathrm{abs}}(\lambda=870 \mathrm{~nm})$ & $1 \mathrm{~s}$ \\
\hline & $\begin{array}{l}\text { High-resolution time-of-flight } \\
\text { aerosol mass spectrometer (HR-AMS) }\end{array}$ & Aerodyne Research, Inc. & $\begin{array}{l}\text { NR-PM } \text { P }_{1} \text { species (organics, sulfate, } \\
\text { nitrate, ammonium, and chloride) }\end{array}$ & $5 \mathrm{~min}$ \\
\hline & $\begin{array}{l}\text { Soot particle aerosol mass spectrometer } \\
\text { (SP-AMS) }\end{array}$ & Aerodyne Research, Inc. & $\begin{array}{l}\mathrm{BC} \text {-containing } \mathrm{PM}_{1} \text { species (rBC, } \\
\text { organics, sulfate, nitrate, ammo- } \\
\text { nium, and chloride) }\end{array}$ & $5 \mathrm{~min}$ \\
\hline \multirow[t]{3}{*}{$260 \mathrm{~m}$} & $\begin{array}{l}\text { Cavity attenuated phase shift particu- } \\
\text { late matter extinction monitor (CAPS } \\
\mathrm{PM}_{\text {ext }}\end{array}$ & Aerodyne Research, Inc. & $\mathrm{PM}_{2.5} b_{\mathrm{ext}}(\lambda=630 \mathrm{~nm})$ & $1 \mathrm{~s}$ \\
\hline & Aethalometer $\left(\mathrm{AE} 33_{2}\right)$ & Magee Scientific Corp. & $\begin{array}{l}\mathrm{eBC}(370,470,520,590,660,880 \text {, } \\
\text { and } 950 \mathrm{~nm})\end{array}$ & $1 \mathrm{~min}$ \\
\hline & $\begin{array}{l}\text { Aerosol chemical species monitor } \\
\text { (ACSM, Aerodyne) }\end{array}$ & Aerodyne Research, Inc. & $\begin{array}{l}\text { NR-PM } \\
\text { nitrate, ammocies (organics, sulfate, } \\
\text { amium, and chloride) }\end{array}$ & $5 \mathrm{~min}$ \\
\hline \multirow[t]{2}{*}{ Vertical } & Photoacoustic Extinctiometer (PAX) & Droplet Measurement Technologies & $\mathrm{PM}_{2.5} b_{\mathrm{sca}}$ and $b_{\mathrm{abs}}(\lambda=870 \mathrm{~nm})$ & $1 \mathrm{~s}$ \\
\hline & Aethalometer $\left(\mathrm{AE} 33_{1}\right)$ & Magee Scientific Corp. & $\begin{array}{l}\text { eBC }(370,470,520,590,660,880 \text {, } \\
\text { and } 950 \mathrm{~nm})\end{array}$ & $1 \mathrm{~s}$ \\
\hline
\end{tabular}
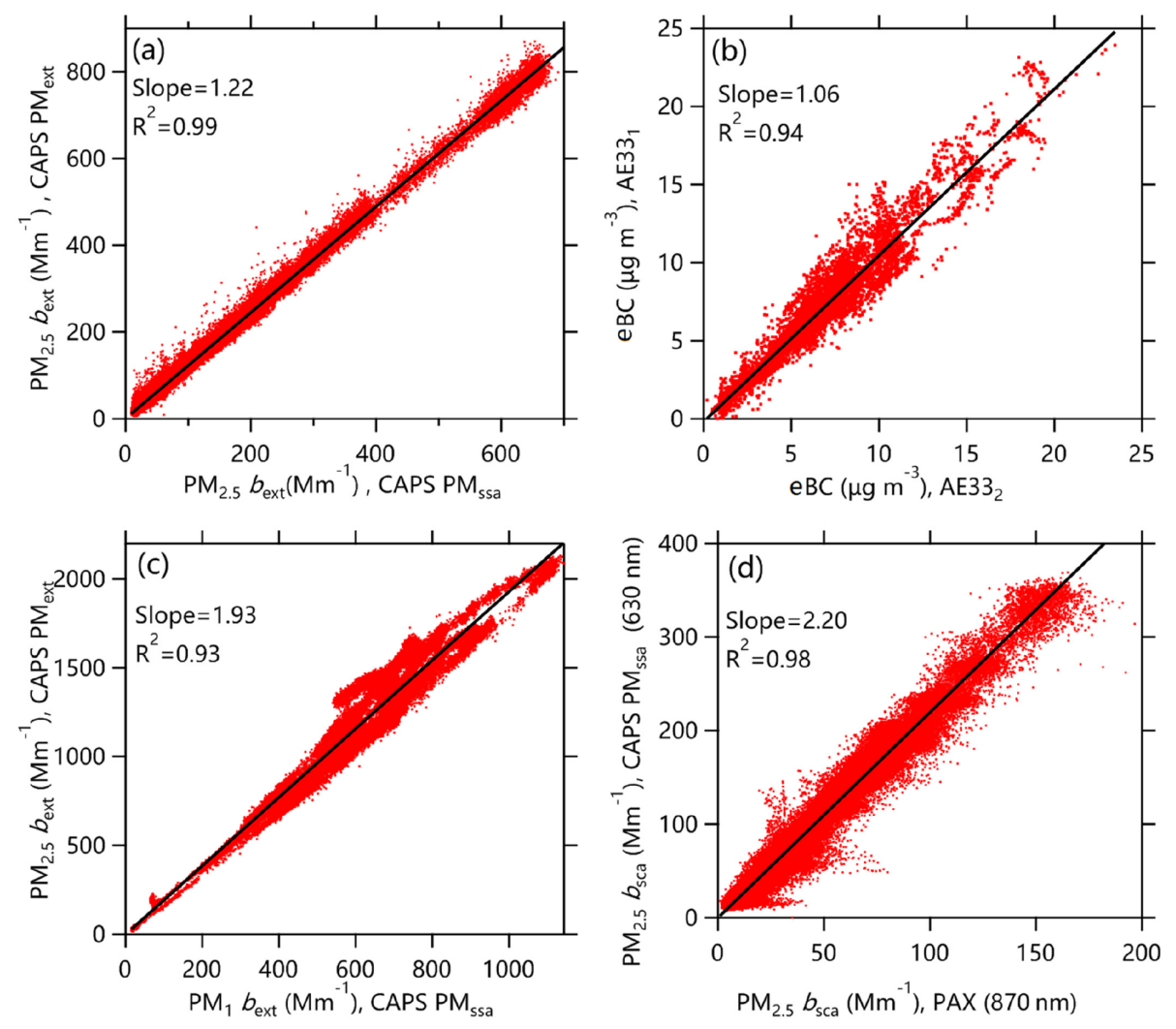

Figure 1. Intercomparisons of aerosol optical properties and BC: (a) $b_{\text {ext }}$ of $\mathrm{PM}_{2.5}$ from CAPS PM $\mathrm{ext}_{\text {and CAPS PM }}$ ssa, (b) eBC from two

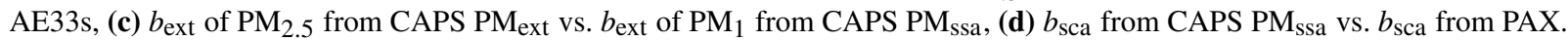



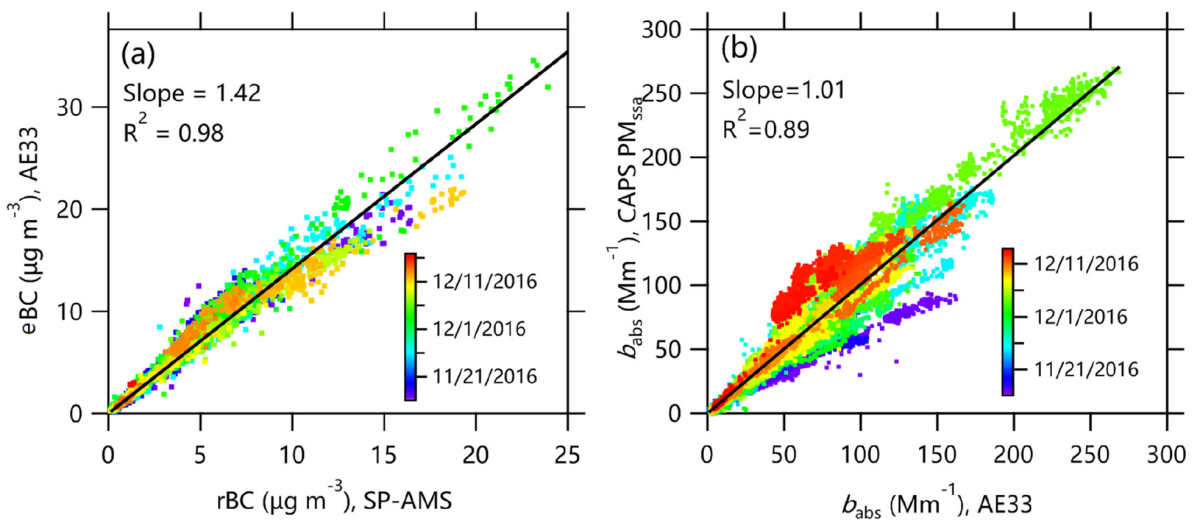

Figure 2. Comparisons of (a) BC measurements between AE33 and SP-AMS and (b) $b_{\text {abs }}$ calculated from the difference of $b_{\text {ext }}$ and $b_{\text {sca }}$ of CAPS $\mathrm{PM}_{\mathrm{ssa}}$ and derived from eBC.

level and $260 \mathrm{~m}$ are both derived as follows:

$\mathrm{SSA}=\frac{b_{\mathrm{ext}}-b_{\mathrm{abs}}}{b_{\mathrm{ext}}}=\frac{b_{\mathrm{ext}}-7.4 \times \mathrm{BC}}{b_{\mathrm{ext}}}$.

Note that all SSA values discussed below refer to $\mathrm{PM}_{2.5}$ at $630 \mathrm{~nm}$ unless otherwise stated.

We also estimate the absorption of $\mathrm{BrC}$, assuming that $\mathrm{BC}$ is the only absorber at $950 \mathrm{~nm}$ with an AAE of 1 (Supplement Fig. S1). The absorption coefficient of BC at $370 \mathrm{~nm}$ is derived using a fitted power law relationship at seven wavelengths (Ran et al., 2016) (Eq. 3). $\mathrm{BrC}$ at $370 \mathrm{~nm}$ is then derived by subtracting the $\mathrm{BC}$ absorption from the total measured absorption (Eq. 4).

$b_{\mathrm{abs}, 370 \mathrm{~nm}, \mathrm{BC}}=b_{\mathrm{abs}, 950 \mathrm{~nm}}\left(\frac{370}{950}\right)^{-\mathrm{AAE}}$,

$b_{\mathrm{abs}, 370 \mathrm{~nm}, \mathrm{BrC}}=b_{\mathrm{abs}, 370 \mathrm{~nm}, \text { Total }}-b_{\mathrm{abs}, 370 \mathrm{~nm}, \mathrm{BC}}$,

where $b_{\mathrm{abs}, 370 \mathrm{~nm}, \mathrm{BC}}$ is the $\mathrm{BC}$ absorption at $370 \mathrm{~nm}$, and $\mathrm{AAE}$ is 1 . It should be noted that we might overestimate $b_{\mathrm{abs}, 370 \mathrm{~nm}, \mathrm{BrC}}$ by approximately $10 \%-20 \%$ if the contribution of "lensing effect" on $\mathrm{BC}$ absorption at $M_{\mathrm{R}}=3$ was negligible (Liu et al., 2017). Although the absorption of dust is much less than those of $\mathrm{BC}$ and $\mathrm{BrC}$ because of much lower MAC (Yang et al., 2009), the data with potential influences of dust as indicated by high Ca content (Fig. S2) were excluded in calculation of the absorption of $\mathrm{BrC}$ at $370 \mathrm{~nm}$.

\section{Results and discussion}

\subsection{General description}

The average $b_{\text {ext }}( \pm 1 \sigma)$ were $547.0 \pm 555.9$ and $387.8 \pm$ $395.2 \mathrm{Mm}^{-1}$ at ground level and $260 \mathrm{~m}$, respectively (Table 2). Compared with previous measurements in winter at the same site (Han et al., 2017; Q. Wang et al., 2018), $b_{\text {ext }}$ is much higher in this study due to the more frequent occurrence of severe haze episodes, e.g., six haze episodes in
Fig. 3. These results suggest that the PM pollution in winter in Beijing was still severe, although air quality has been continuously improved in recent years. We also note that the average $b_{\text {ext }}$ at $260 \mathrm{~m}$ was on average $29.1 \%$ lower than that at ground level, suggesting a considerable vertical gradient in $b_{\text {ext }}$ in winter.

As shown in Fig. 3, $b_{\text {sca }}$ and $b_{\text {abs }}$ varied similarly to $b_{\text {ext }}$, and the average $b_{\text {sca }}$ and $b_{\text {abs }}$ at $260 \mathrm{~m}$ were $337.6( \pm 356.0)$ and $36.6( \pm 33.9) \mathrm{Mm}^{-1}$, respectively, which were $26.5 \%$ and $22.5 \%$ lower than those at ground level $(459.5 \pm 483.1$ and $47.2 \pm 2.4 \mathrm{Mm}^{-1}$, respectively). Since the SSA is the ratio of $b_{\text {sca }}$ and $b_{\text {ext }}$, the variations in SSA at ground level were similar to those at $260 \mathrm{~m}$ for most of the time, although several periods with much lower SSA at ground level were observed due to large emissions of $\mathrm{BC}$ at midnight, e.g., 17 November and 1 December. The average $( \pm 1 \sigma)$ SSA was $0.89( \pm 0.04)$ and $0.88( \pm 0.04)$ at ground level and $260 \mathrm{~m}$, respectively, which was overall consistent with those (0.840.91) in previous studies (Han et al., 2015, 2017; Q. Wang et al., 2018). Figure 3 also shows that high SSA values were typically associated with haze episodes while low values typically occur during clean periods. These results suggest an increasing role of scattering aerosols, e.g., secondary inorganic aerosol species, during haze episodes.

\subsection{Vertical differences of aerosol optical properties}

All aerosol optical properties including $b_{\text {ext }}, b_{\text {sca }}$, and $b_{\text {abs }}$ showed overall similar variations between ground level and $260 \mathrm{~m}$, with $R^{2}$ between ground level and $260 \mathrm{~m}$ varying from 0.70 to 0.81 . However, large vertical differences were also observed during specific periods, for example, the cleaning stages of haze episodes (26 November, 4 and 7 December), and several midnights with largely enhanced BC emissions (17 and 29 November). As indicated in Fig. 4a and b, the periods with low values of ratio $260 \mathrm{~m} /$ ground were characterized by correspondingly low MLH (typically less than $300 \mathrm{~m}$ ) and much higher RH at ground level than $260 \mathrm{~m}$. Fig- 


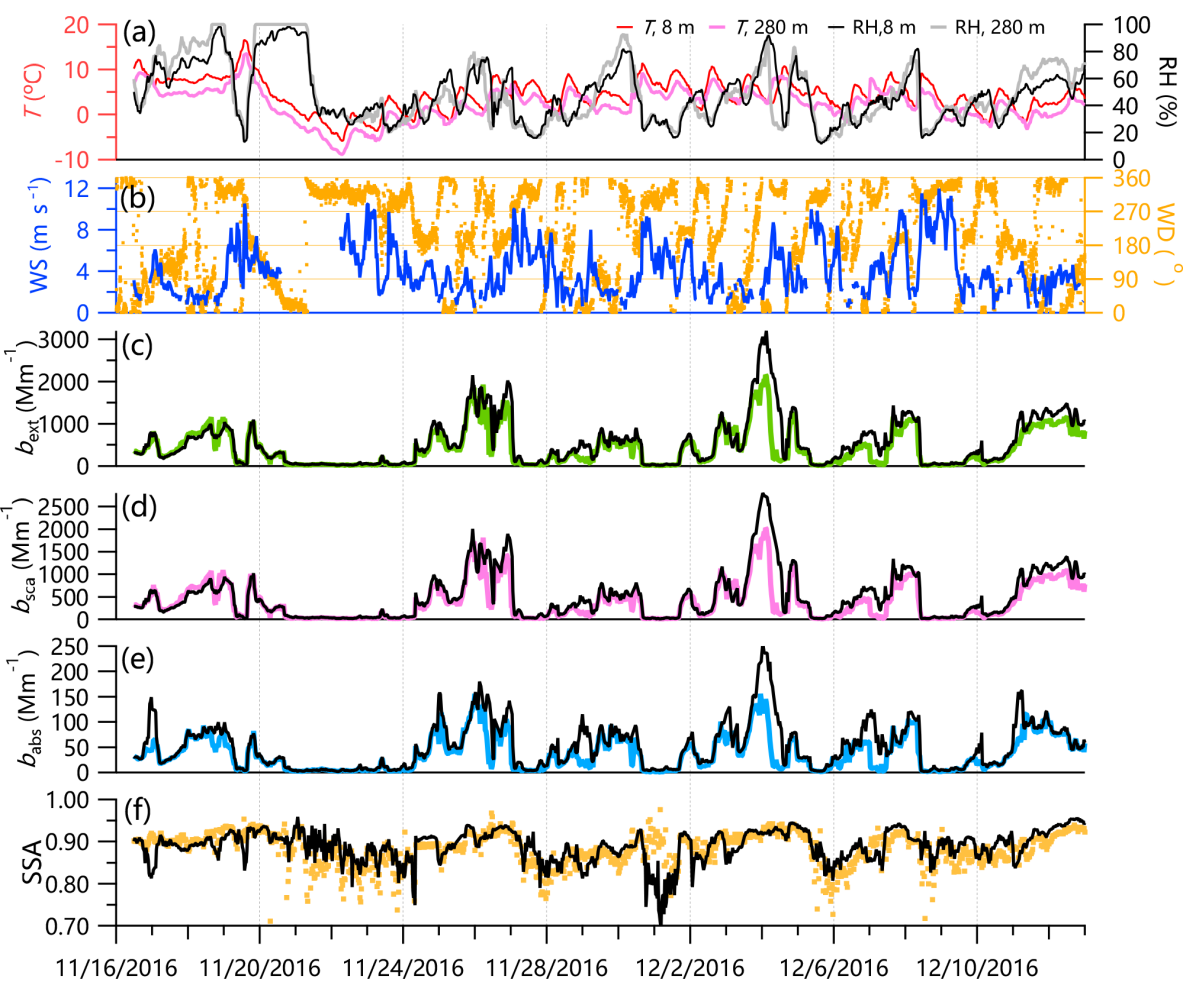

Figure 3. Temporal variations of (a) temperature $(T)$ and relative humidity (RH) at ground level and $280 \mathrm{~m}$, (b) wind speed (WS) and wind direction (WD) at $280 \mathrm{~m}$, and comparisons of the time series of optical properties of $\mathrm{PM}_{2.5}$ between ground level (black lines) and $260 \mathrm{~m}$ (colored lines): (c) $b_{\text {ext }}$, (d) scattering coefficient, (e) absorption coefficient, (f) SSA.

ure 5 further shows that the vertical ratios $260 \mathrm{~m} /$ ground of $b_{\text {sca }}$ and $b_{\text {abs }}$ varied substantially throughout the study with the values below 1 for most of the time ( $89 \%$ and $84 \%$, respectively). These results suggest that the vertical differences of aerosol optical properties were complex in winter in Beijing, but overall higher heights showed lower values. We also observed different frequencies of the ratio $260 \mathrm{~m} /$ ground between $b_{\text {sca }}$ and $b_{\text {abs }}$ (Fig. 5). While the ratio $260 \mathrm{~m} /$ ground of $b_{\text {sca }}$ varied mainly between 0.6 and 0.8 , that of $b_{\text {abs }}$ was between 0.8 and 1.0, highlighting the different contributions of scattering and absorbing aerosols at different heights. Although $b_{\mathrm{abs}}$ at $260 \mathrm{~m}$ was $21 \%$ lower than that at ground level (37 vs. $47 \mathrm{Mm}^{-1}$ ), the relative contribution of absorbing aerosols was relatively higher. One reason is that a large fraction of $\mathrm{BC}$ in Beijing is from regional transport (Sun et al., 2016), and the ratio of $\mathrm{BC}$ to scattering aerosol species in Beijing's surrounding regions is high, likely due to the strict control of heavy-duty and diesel trucks and also much reduced coal combustion emissions in the city of Beijing.

Figure 6 shows the diurnal cycles of aerosol optical properties at $260 \mathrm{~m}$ and ground level after excluding the periods with cleaning processes, while those of entire study are presented in Fig. S3. The diurnal profiles of $b_{\text {sca }}$ and $b_{\text {abs }}$ were overall similar between ground level and $260 \mathrm{~m}$, which were both characterized by higher values at night and lower values during daytime. Such diurnal patterns were opposite to those of MLH, which showed gradual increases from 300$400 \mathrm{~m}$ at nighttime to $\sim 600-700 \mathrm{~m}$ in the late afternoon (Fig. 5a). These results indicate that the variation of PBL height plays an important role in driving the diurnal variations of aerosol optical properties. This is further supported by the diurnal variations in ratios $260 \mathrm{~m} /$ ground, and correlations between $260 \mathrm{~m}$ and ground $\left(R_{260 \mathrm{~m} \text { vs. ground }}^{2}\right)$. As shown in Fig. 6, the ratio $260 \mathrm{~m} /$ ground of $b_{\text {sca }}$ increased from $\sim 0.70$ at nighttime to $\sim 0.85$ during daytime, while that of $b_{\mathrm{abs}}$ increased from 0.71 to 0.96 as a result of rising PBL. $R^{2}$ of $b_{\text {sca }}$ and $b_{\text {abs }}$ also increased up to $>0.90$, suggesting that scattering and absorbing aerosols were relatively well mixed vertically. Because of the influences of enhanced local primary emissions and the reduced vertical mixing, both ratios and $R^{2}$ of $b_{\text {abs }}$ between $260 \mathrm{~m}$ and ground level decreased substantially at nighttime. It should be noted that the ratio $260 \mathrm{~m} /$ ground of $b_{\text {sca }}$ did not reach 1 in the late afternoon even when the MLH was above $300 \mathrm{~m}$. These results suggest that other factors also contributed the vertical differences of $b_{\text {sca }}$ in addition to MLH. For example, $b_{\text {sca }}$ is mainly contributed by secondary aerosols (e.g., ammonium sulfate, ammonium nitrate, and SOA) (Han et al., 2015; Wang et al., 2015), while the secondary production at different heights could be different due to the different precursor concentrations and oxidants and also different phase partitioning, since $T$ falls and RH increases with height. Secondary aerosols are typically formed 

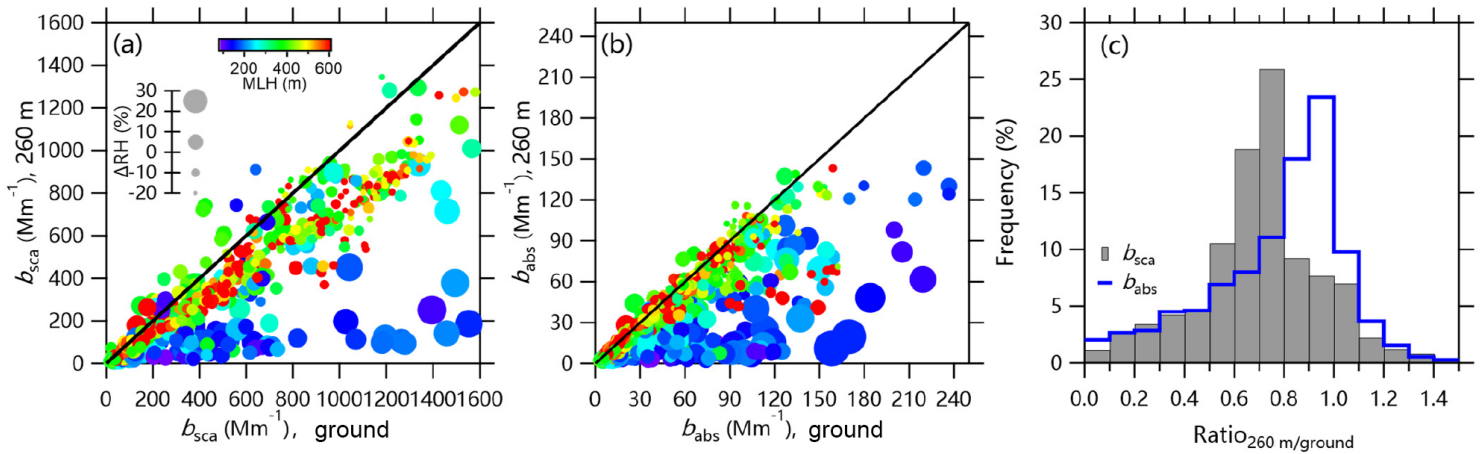

Figure 4. Comparisons of (a) $b_{\text {sca }}$ and (b) $b_{\text {abs }}$ between $260 \mathrm{~m}$ and ground level. The scatter plot is color coded by mixed layer height, and the marker size is proportional to the RH difference between ground level and $280 \mathrm{~m}$. Panel (c) shows the frequencies of ratios of $260 \mathrm{~m}$ to ground level for $b_{\text {sca }}$ and $b_{\text {abs }}$.

Table 2. A summary of average $( \pm 1 \sigma)$ meteorological parameters and optical properties at ground level and $260 \mathrm{~m}$ during this study.

\begin{tabular}{|c|c|c|c|}
\hline & $260 \mathrm{~m}$ & Ground & $R_{260 \mathrm{~m} / \text { Ground }}$ \\
\hline \multicolumn{4}{|c|}{ Meteorological parameters } \\
\hline$T\left({ }^{\circ} \mathrm{C}\right)$ & $2.3 \pm 3.7$ & $4.3 \pm 3.7$ & 0.53 \\
\hline $\mathrm{RH}(\%)$ & $49.1 \pm 23.5$ & $48.5 \pm 20.7$ & 1.01 \\
\hline $\mathrm{WS}\left(\mathrm{ms}^{-1}\right)$ & $4.0 \pm 2.4$ & $1.4 \pm 1.0$ & 2.85 \\
\hline \multicolumn{4}{|c|}{ Optical properties } \\
\hline$b_{\text {ext }}\left(\mathrm{Mm}^{-1}\right)$ & $387.8 \pm 395.2$ & $547.0 \pm 555.9$ & 0.71 \\
\hline$b_{\mathrm{sca}}\left(\mathrm{Mm}^{-1}\right)$ & $337.6 \pm 356.0$ & $459.5 \pm 483.1$ & 0.73 \\
\hline$b_{\mathrm{abs}}\left(\mathrm{Mm}^{-1}\right)$ & $36.6 \pm 33.9$ & $47.2 \pm 2.4$ & 0.78 \\
\hline SSA & $0.88 \pm 0.04$ & $0.89 \pm 0.04$ & 0.98 \\
\hline AAE & $1.60 \pm 0.18$ & $1.58 \pm 0.15$ & 1.01 \\
\hline
\end{tabular}

over a regional scale, which also supports the good correlations of $b_{\text {sca }}$ between ground level and $260 \mathrm{~m}$ at nighttime.

SSA at ground level showed a clear diurnal trend, with the values increasing from 0.85 at 08:00 to 0.89 at 12:00, and then remained at relatively high levels in the late afternoon. Such a diurnal profile is most likely related to photochemical production of secondary aerosol in the daytime, which is supported by the gradual increase in SSA as a function of photochemical age $\left(-\log \left(\mathrm{NO}_{x} / \mathrm{NO}_{y} ; \mathrm{Fig}\right.\right.$. S4). Note that the diurnal variation of SSA is relatively smaller than those in autumn and summer at the same site (Han et al., 2015, 2017). A possible explanation is that the enhancement of light scattering caused by photochemical production is weaker in winter. The diurnal profile of SSA at $260 \mathrm{~m}$ was relatively similar to that at ground level, but the variations were much smaller. We also noticed that SSA at ground level was lower than that at $260 \mathrm{~m}$ at nighttime due to enhanced light absorption of BC from local emissions. Indeed, such diurnal differences are closely related to composition differences between ground level and $260 \mathrm{~m}$ (Zhao et al., 2017).

\subsection{Evolution of vertical profiles of aerosol optical properties.}

A total of 50 vertical profiles of $b_{\text {sca }}$ and $b_{\mathrm{abs}}$ from ground level to $260 \mathrm{~m}$ (day) or $240 \mathrm{~m}$ (night) were obtained in this study (Table S1 and Fig. S5). As shown in Fig. 5, the vertical ratios of $b_{\text {sca }}$ and $b_{\text {abs }}$ between ground level and 240 or $260 \mathrm{~m}$ agreed well with those determined from simultaneous real-time measurements at the two heights. Although the ratios $260 /$ ground of $b_{\text {sca }}$ and $b_{\text {abs }}$ varied largely from $\sim 0.1$ to 1.6, those of SSA showed small vertical differences for most of the time, e.g., $<0.04$. Figure 7 presents the evolution of vertical profiles during a severe haze episode on 2-4 December. Before the formation of the haze episode, aerosol particles were relatively well mixed vertically, and the vertical differences of $b_{\text {sca }}$ and $b_{\text {abs }}$ (M16 and M17) were both less than $30 \%$. This was consistent with the high MLH $(\sim 600 \mathrm{~m})$ during this period of time. After M16 (16:00), $b_{\mathrm{ext}}$ increased rapidly from less than 100 to $>300 \mathrm{Mm}^{-1}$ in $4 \mathrm{~h}$ associated with a decrease in MLH from $\sim 600$ to $\sim 400 \mathrm{~m}$ and a change of air masses from the north to the southwest. We note that $b_{\text {sca }}$ and $b_{\text {abs }}$ increased simultaneously across different heights, suggesting that both regional transport and the decrease in MLH have played important roles in the formation of this haze episode. However, SSA showed a gradual increase from $\sim 0.82$ (M16) to $\sim 0.90$ (M19), consistent with the large increases in the contributions of scattering nitrate and SOA during this period (Xu et al., 2018).

The vertical profiles showed significant changes at nighttime (M19 and M20) when $T$ inversion occurred frequently. As shown in Fig. 8c, a strong $T$ inversion by approximately $1{ }^{\circ} \mathrm{C}$ was observed between 150 and $320 \mathrm{~m}$, and RH was decreased by $\sim 5 \%$. While $b_{\text {sca }}$ and $b_{\text {abs }}$ were vertically relatively well mixed below the $T$ inversion, they had significant changes in both absolute values and relative contributions above the layer. In particular, SSA increased considerably from $\sim 0.81-0.82$ to $\sim 0.88-0.90$ above the $T$ inversion, suggesting that scattering and absorbing aerosols 


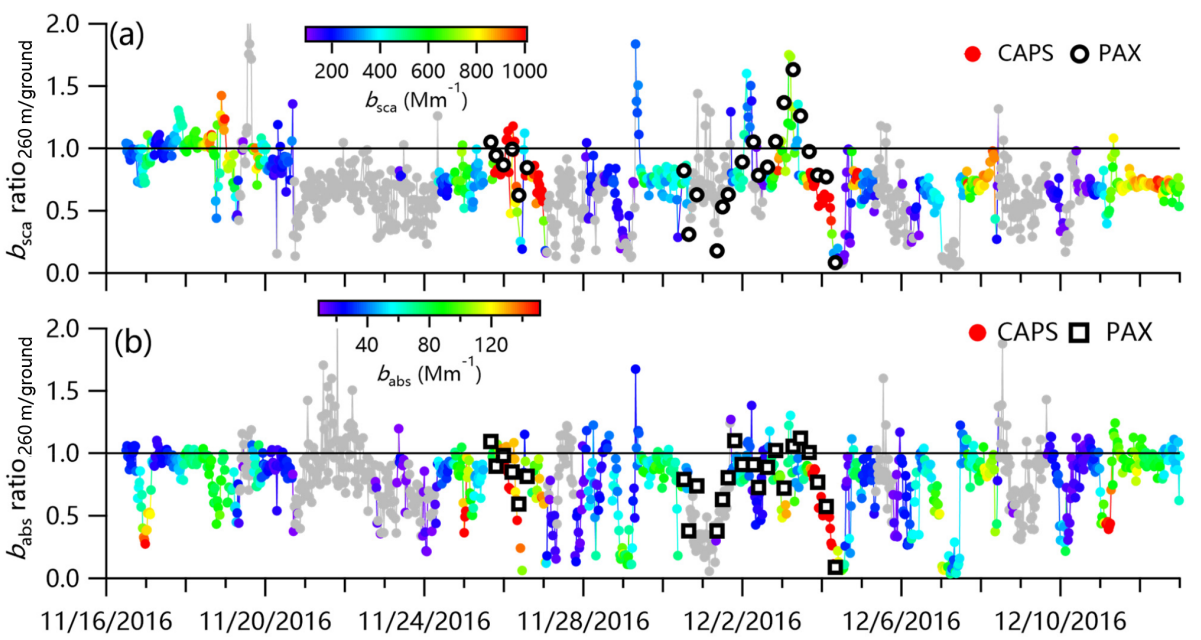

Figure 5. Time series of hourly average ratios $260 \mathrm{~m} /$ ground for $b_{\text {sca }}$ and $b_{\text {abs }}$ during this study. The ratios are color coded by $b_{\text {ext }}$, and the black circles and squares are those from continuous vertical measurements with PAX.
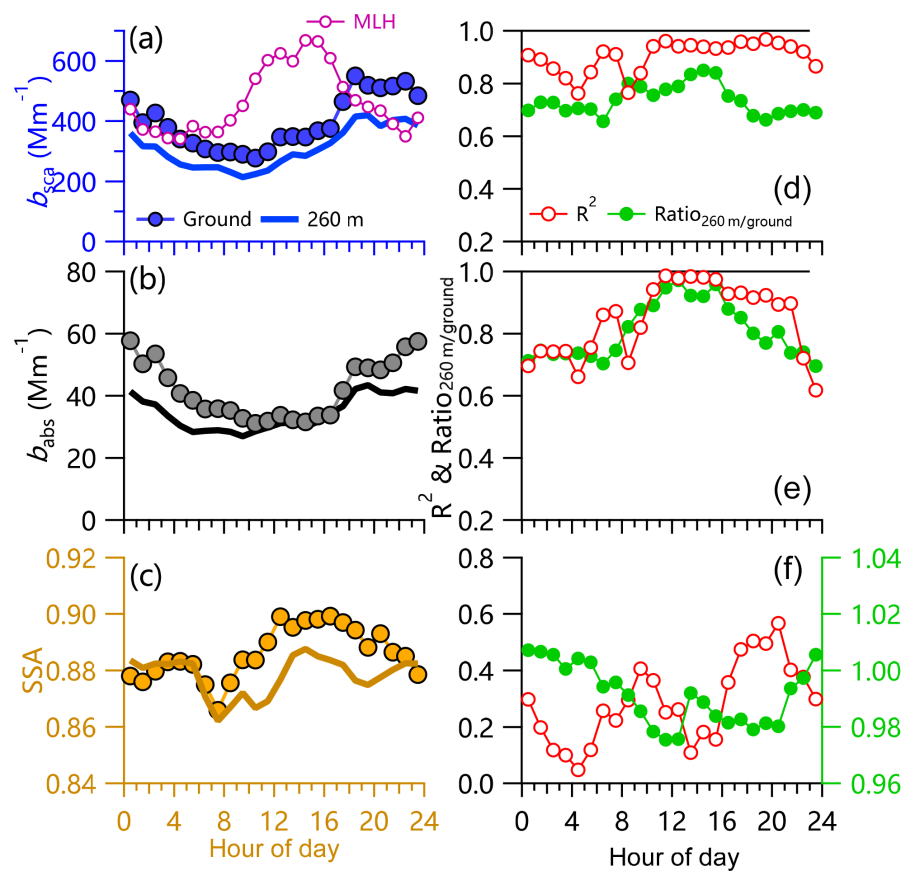

Figure 6. Diurnal cycles of (a) $b_{\mathrm{sca}}$, (b) $b_{\mathrm{abs}}$, and (c) SSA at $260 \mathrm{~m}$ and ground level for the entire study. Panels (d, e, f) show the diurnal cycles of correlation coefficients $\left(R^{2}\right)$ and ratio $260 \mathrm{~m} /$ ground for $b_{\text {sca }}, b_{\text {abs }}$, and SSA. Note that the diurnal cycles above excluded five periods with cleaning processes (19 November 01:00 to 09:00, 26 November 01:00 to 12:00, 26 November 19:00 to 27 November 03:00, 3 December 20:00 to 4 December 16:00, and 17 December 00:00 to 12:00) while those of entire study are shown in Fig. S3.

differed significantly below and above $T$ inversion. In fact, aerosol composition at ground level during M19 and M20 was characterized by higher BC $(10 \%)$ and organics (48\%$54 \%$ ) than that at $260 \mathrm{~m}$ ( $8 \%$ and $44 \%-46 \%$, respectively), and secondary nitrate was correspondingly low (16\%-17\% vs. $23 \%$ ). Because of the $T$ inversion, the enhanced lightabsorbing aerosol from local emissions could not be well mixed at $260 \mathrm{~m}$, leading to lower SSA at ground level. In addition, the higher mass fraction of scattering secondary inorganic aerosol (SIA) at $260 \mathrm{~m}$ could also increase the SSA independently (Fig. S6). Air pollution was the severest on the night of 3 December, which was associated with a large increase in RH below $200 \mathrm{~m}$, mostly likely a light fog event and consistently low MLH $(<200 \mathrm{~m})$. As a result, large vertical differences were observed for both $b_{\text {sca }}$ and $b_{\text {abs. In par- }}$ ticular, $b_{\text {sca }}$ and $b_{\text {abs }}$ start to decrease at $\sim 120 \mathrm{~m}$, and the 


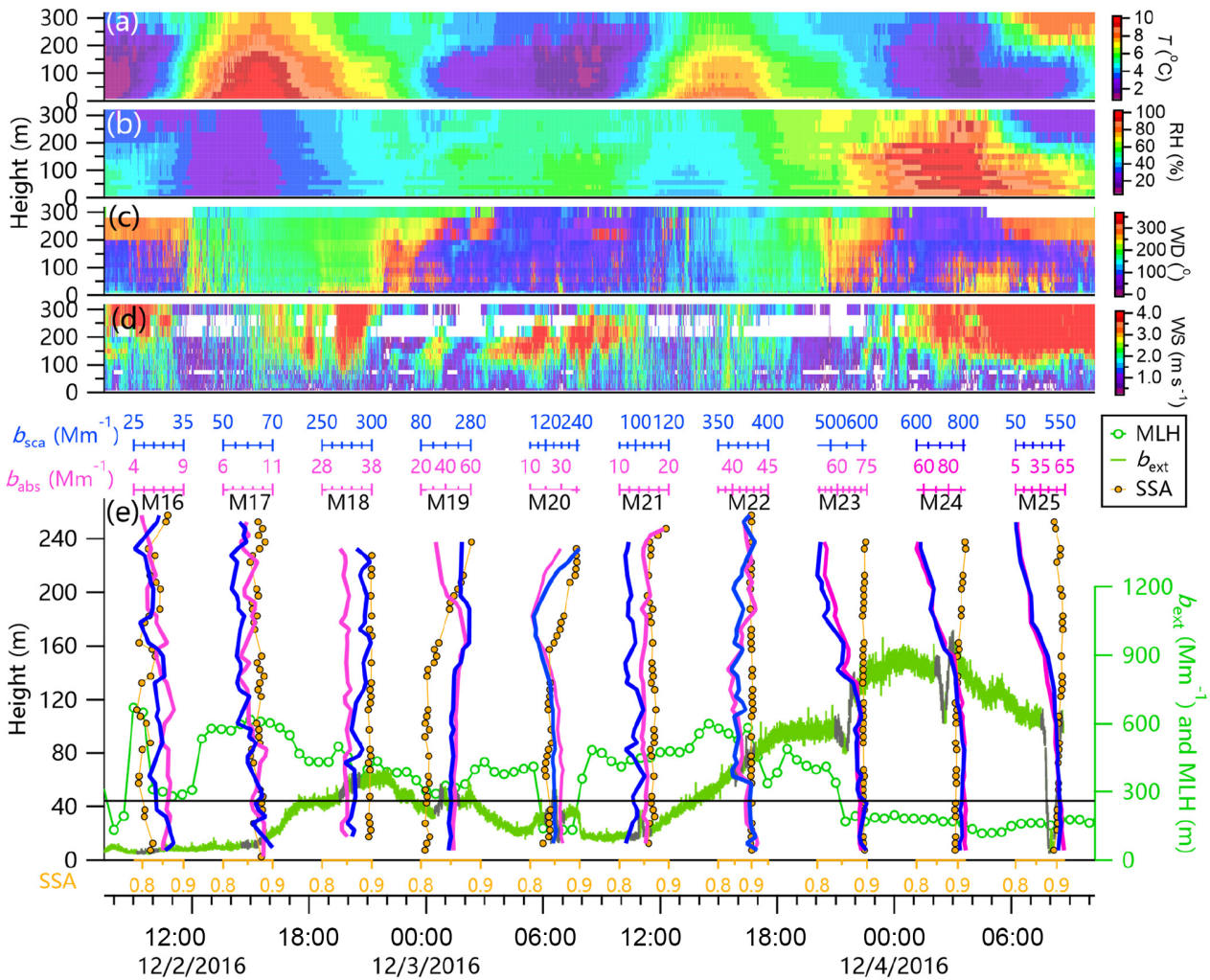

Figure 7. Evolution of vertical profiles of $b_{\text {sca }}, b_{\text {abs }}$, and SSA during 2-4 December. Also shown are (a-d) meteorological variables of $T$, $\mathrm{RH}, \mathrm{WD}$, and WS, as well as (e) time series of $b_{\text {ext }}$ at ground and MLH. M16-M25 refer to the number of vertical profiles.

ratios $240 \mathrm{~m} /$ ground decrease rapidly from $\sim 0.8(\mathrm{M} 23)$ to $<0.1$ (M25). Such large vertical gradients were also due to the earlier cleaning of air pollutants at higher heights (Fig. 7d). Although the vertical changes in $b_{\text {sca }}$ and $b_{\text {abs }}$ were significant, those of SSA were small, which were due to the small changes in relative contributions of $\mathrm{BC}$ and non-BC aerosols at ground level and $260 \mathrm{~m}$ during this period of time (Xu et al., 2018). Our results suggest that vertical profiles of aerosol optical properties can have significant changes during the formation and evolution of haze episodes depending on changes in meteorological conditions and source emissions.

\subsection{MAC of eBC}

Figure 9a shows that the MAC of eBC increased substantially from 9.5 to $13.2 \mathrm{~m}^{2} \mathrm{~g}^{-1}$ as the mass ratio of non-rBC material to $\mathrm{rBC}$ in $\mathrm{rBC}$-containing particles $\left(M_{\mathrm{R}}\right)$ increased from 3.2 to 6.7. Considering that the light absorption of $\mathrm{BrC}$ at $630 \mathrm{~nm}$ was relatively small, the increases in MAC could be mainly due to the lensing effect of BC-coated materials. The average $M_{\mathrm{R}}$ is $4.66( \pm 0.95)$, indicating that most $\mathrm{rBC}$ containing particles contain a large amount of non-rBC constituents. According to SP-AMS measurements, the average composition of rBC-containing particles was dominated by organics $(59 \%)$ and $\mathrm{rBC}(17 \%)$, of which $66 \%$ of organics are from primary emissions of coal combustion and biomass burning (J. Wang et al., 2018). This is also consistent with low $\mathrm{O} / \mathrm{C}$ ratios $(<0.3)$ during this study (Fig. 10b). Although the $\mathrm{rBC}$-coated materials were dominated by primary aerosol, the increases in MAC were more associated with secondary aerosol. As shown in Fig. 9b, the contributions of POA (BBOA + FFOA) decreased from $67 \%$ to $16 \%$ as $M_{\mathrm{R}}$ increased from 3 to 7 ; in contrast, the contributions of secondary aerosol species (= SOA + SIA) increased from $29 \%$ to $80 \%$. This was also supported by the correlations between MAC and $M_{\mathrm{R}}$ across different levels. As shown in Fig. 9a, the increases in MAC as a function of $M_{\mathrm{R}}$ were relatively small, typically less than $20 \%$ at low PM levels $\left(<100 \mu \mathrm{g} \mathrm{m}^{-3}\right)$ when the contribution of POA was much higher than that of secondary aerosol species ( $37 \%$ vs. $59 \%$ ), while MAC increased significantly by nearly $40 \%$ during periods with high PM levels $\left(>150 \mu \mathrm{g} \mathrm{m}^{-3}\right.$ ) and a higher contribution of secondary aerosol (Fig. S7). We also found that the increases in MAC and $M_{\mathrm{R}}$ were both associated with the corresponding increases in $\mathrm{O} / \mathrm{C}$ ratios, indicating that photochemical processing plays an important role in changing the MAC and coating of $\mathrm{BC}$ in winter. Indeed, MAC showed a pronounced diurnal cycle with a clear daytime increase from $\sim 11$ to $\sim 13 \mathrm{~m}^{2} \mathrm{~g}^{-1}$, (Fig. 10a), and such a diurnal pattern agreed well with that of $\mathrm{O} / \mathrm{C}$, an indicator of the extent of chemical 

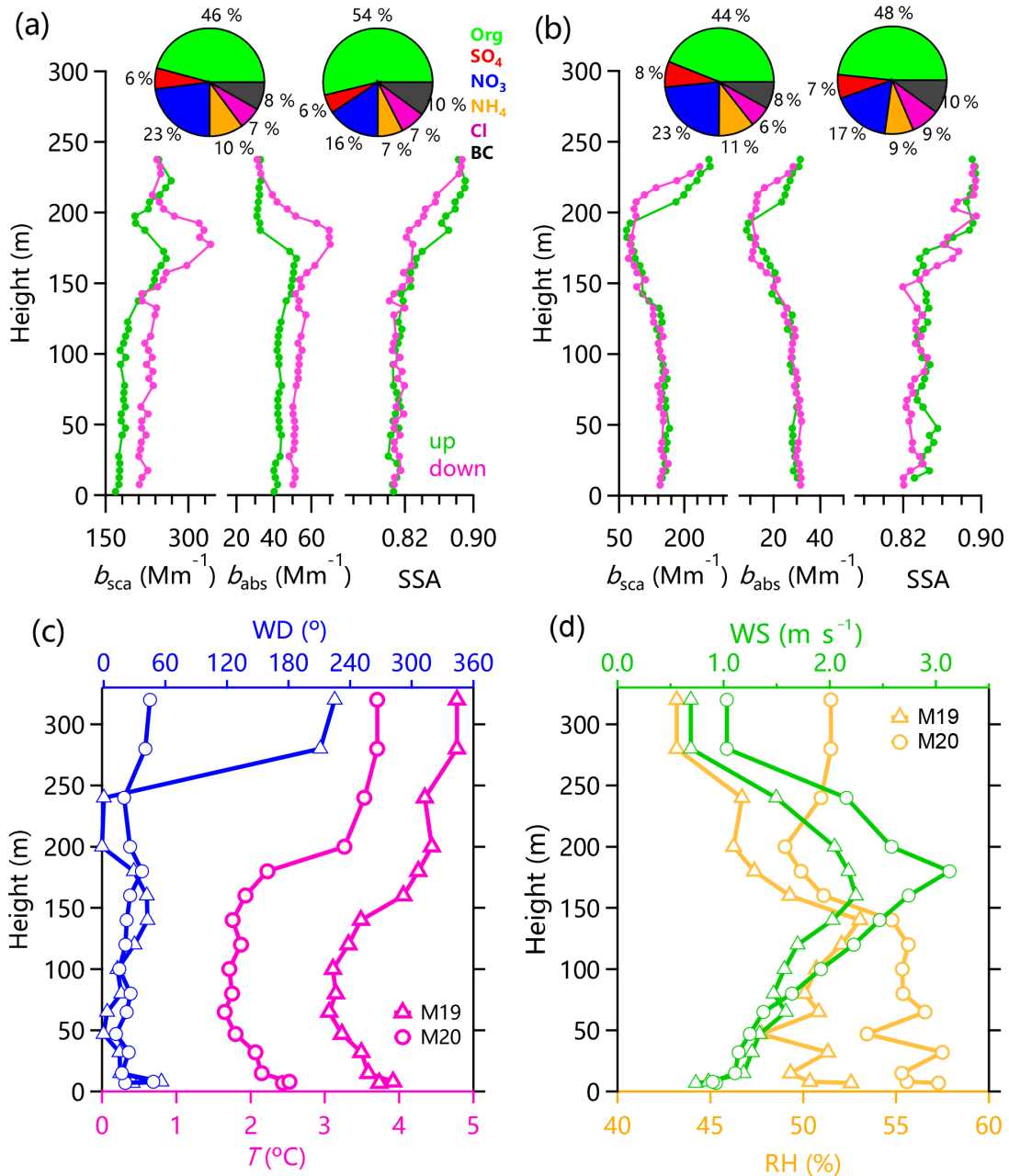

Figure 8. Vertical profiles of $b_{\text {sca }}, b_{\text {abs }}$, and SSA measured by PAX at $880 \mathrm{~nm}$ during (a) M19 and (b) M20. Panels (c) and (d) show the average vertical profiles of T, RH, WS, and WD during M19 and M20, respectively. The pie charts show average chemical composition of $\mathrm{PM}_{1}$ at $260 \mathrm{~m}(\mathbf{a}, \mathbf{c})$ and ground level $(\mathbf{b}, \mathbf{d})$ during M19 and M20, respectively.
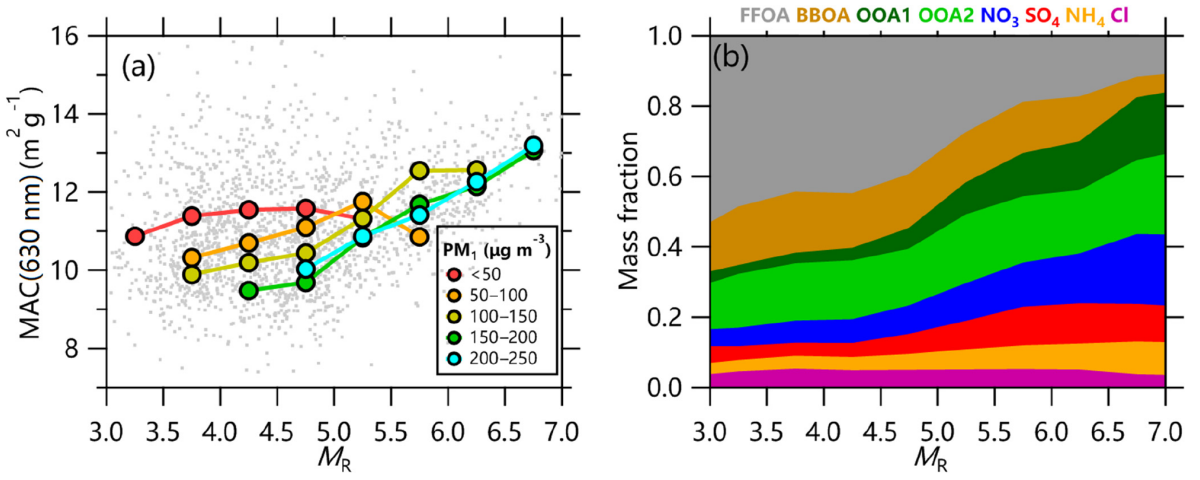

Figure 9. (a) Variations of MAC as a function of $M_{\mathrm{R}}$ at different pollution levels and (b) variations of mass fraction of rBC-coated species as a function of $M_{\mathrm{R}}$.

aging of organic aerosol. Consistently, MAC was almost linearly correlated with $\mathrm{O} / \mathrm{C}$, as indicated in Fig. 10b. As O / C increased from 0.1 to 0.25 , MAC increased from $\sim 10$ to
$14 \mathrm{~m}^{2} \mathrm{~g}^{-1}$. These results suggest that secondary production from photochemical processing can contribute to the light 


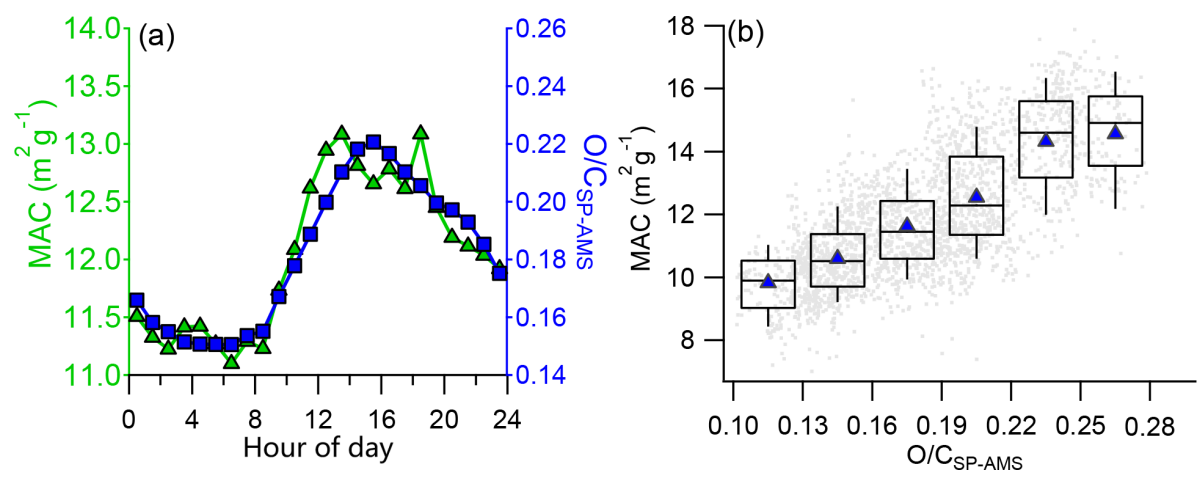

Figure 10. (a) Diurnal cycles of MAC and O / C ratio of SP-AMS (O / $\left.\mathrm{C}_{\mathrm{SP}-\mathrm{AMS}}\right)$, and (b) variations of MAC as a function of O / $\mathrm{C}_{\mathrm{SP}-\mathrm{AMS}}$. The data are binned according to $\mathrm{O} / \mathrm{C}$. The median (horizontal line), mean (triangle), 25th and 75th percentiles (lower and upper box), and 10th and 90th percentiles (lower and upper whiskers) are also shown.

absorption enhancement of $\mathrm{BC}$ in daytime by approximately $20 \%$, and up to $40 \%$ in this study.

\subsection{Brown carbon}

As shown in Fig. S8, the average AAE values derived from the wavelength-dependent absorption were 1.58 and 1.60 at the ground and at $260 \mathrm{~m}$, respectively, indicating the importance of non-BC light absorbers. Indeed, the absorption of $\mathrm{BrC}\left(b_{\mathrm{abs}, \mathrm{BrC}}\right)$ on average accounts for $46 \%$ and $48 \%$ (Fig. S1) of the total absorption at $370 \mathrm{~nm}$ at ground level and $260 \mathrm{~m}$, supporting the importance of $\mathrm{BrC}$ absorption at ultraviolet wavelength. It should be noted that the extraction of $b_{\mathrm{abs}, \mathrm{BrC}}$ from total absorption may introduce uncertainty since the AAE of $\mathrm{BC}$ is also influenced by $\mathrm{BC}$ size and coatings (D. Liu et al., 2015). It is interesting to note that the fraction of $b_{\mathrm{abs}, \mathrm{BrC}}$ in $b_{\mathrm{abs}}$ increased from $\sim 0.35$ to $\sim 0.5$ and the ratio of organics between SP-AMS and HRAMS also increases, suggesting that $\mathrm{rBC}$-related OA materials were more light-absorbing than the total OA. In fact, the organic mass measured by the SP-AMS is dominated by coal combustion and biomass burning emissions (J. Wang et al., 2018), two important sources of BrC (Yan et al., 2015; Sun et al., 2017; Du et al., 2014). Further supporting evidence includes the fact that the mass absorption coefficient of $\mathrm{BrC}\left(\mathrm{MAC}_{\mathrm{org}}, 370 \mathrm{~nm}\right)$ showed a pronounced diurnal cycle, with higher values at nighttime, consistent with the enhanced nighttime primary emissions in winter. Figure 11a also shows that the nighttime $b_{\mathrm{abs}, \mathrm{BrC}}$ at ground level was much higher than that at $260 \mathrm{~m}$. One explanation is that a large amount of local primary emissions at nighttime is not well vertically transported to $260 \mathrm{~m}$. The small late-afternoon peak indicates that secondary aerosol from photochemical production can also contribute to the $\mathrm{BrC}$ absorption.

$b_{\mathrm{abs}, \mathrm{BrC}}$ correlated the best with BBOA and FFOA $\left(R^{2}=\right.$ 0.83 and 0.81 , respectively) and moderately correlated with photochemical SOA $\left(R^{2}=0.46\right)$ at ground level. These results suggest that biomass burning, coal combustion, and photochemical production are three major sources of $\mathrm{BrC}$ in winter. We then estimated the contributions of different $\mathrm{OA}$ sources to $\mathrm{BrC}$ using a multiple linear regression model, as indicated by Eq. (5), and PMF with OA factors and $\mathrm{BrC}$ absorption as input.

$$
\begin{gathered}
b_{\mathrm{abs}, \mathrm{BrC}}=m_{1} \times[\mathrm{FFOA}]+m_{2} \times[\mathrm{COA}]+m_{3} \times[\mathrm{BBOA}] \\
+m_{4} \times[\mathrm{OOA}]+m_{5} \times[\mathrm{OPOA}]+m_{6} \times[\mathrm{aq}-\mathrm{OOA}]
\end{gathered}
$$

The results are very consistent between the two approaches, which both show that coal combustion is the major source contribution of $\mathrm{BrC}$ at ground level, on average accounting for $48 \%-55 \%$ (Fig. 12). The contributions of $\mathrm{BBOA}$ and $\mathrm{OOA}$ to $\mathrm{BrC}$ were comparable, at $17 \%$ and $19 \%-20 \%$, respectively. In comparison, cooking emissions and aqueous-phase processing tend to provide minor contributions of $\mathrm{BrC}$ in winter in Beijing. Our results are consistent with a recent study which highlighted the importance of fossil source contribution to $\mathrm{BrC}$ in winter in Beijing (Yan et al., 2017). Also, large contributions of BBOA and OOA to BrC were also observed in Switzerland during winter (Moschos et al., 2018).

\section{Conclusions}

We conducted comprehensive measurements of aerosol optical properties at both ground level and $260 \mathrm{~m}$ in winter in Beijing using a suite of state-of-the-art instruments, e.g., two CAPSs, two AE33s, SP-AMS, and PAX. The intercomparisons showed excellent agreements among different instruments. $b_{\text {ext }}, b_{\text {sca }}$, and $b_{\text {abs }}$ varied dynamically throughout the campaign, but overall showed similar trends between ground level and $260 \mathrm{~m}$. On average, $b_{\text {sca }}$ and $b_{\text {abs }}$ were 337.6 and $36.6 \mathrm{Mm}^{-1}$ at $260 \mathrm{~m}$, which are $26.5 \%$ and $22.5 \%$ lower than those at ground level (459.5 and $47.2 \mathrm{Mm}^{-1}$, respectively). In fact, ratios $260 \mathrm{~m} /$ ground of $b_{\text {sca }}$ and $b_{\text {abs }}$ varied substantially from $<0.1$ to $\sim 1.5$, indicating very complex verti- 

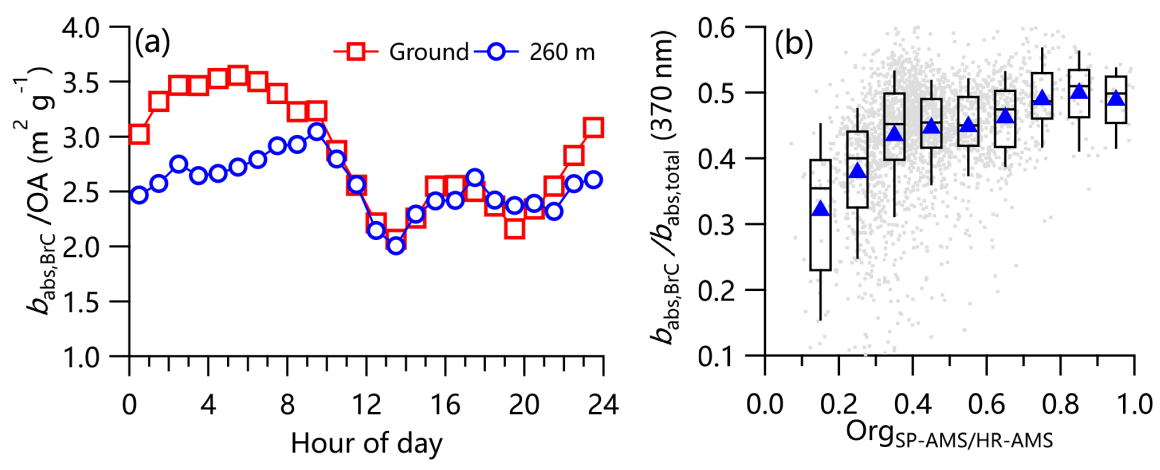

Figure 11. (a) Diurnal cycles of $b_{\mathrm{abs}, \mathrm{BrC}} / \mathrm{OA}$, i.e., $\mathrm{MAC}_{\mathrm{org}, 370 \mathrm{~nm}}$ at ground level and $260 \mathrm{~m}$, (b) variations of the ratio of $\mathrm{BrC}$ absorption to the total absorption at $370 \mathrm{~nm}$ as a function of the ratio of organics between SP-AMS and HR-AMS. The data are binned according to $\mathrm{O} / \mathrm{C}$. The median (horizontal line), mean (triangle), 25th and 75th percentiles (lower and upper box), and 10th and 90th percentiles (lower and upper whiskers) are also shown.
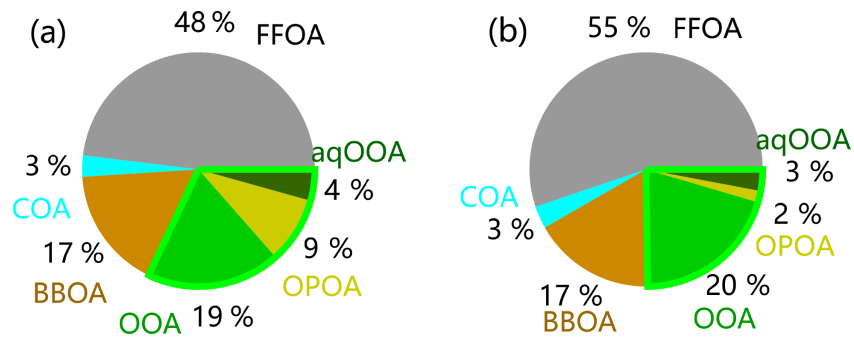

Figure 12. Average contributions of $\mathrm{OA}$ sources to $\mathrm{BrC}$ absorption at ground level from (a) a linear regression model, and (b) positive matrix factorization (Fig. S9). The sources of OA include fossilfuel-related OA (FFOA), cooking OA (COA), biomass burning OA (BBOA), oxygenated OA (OOA), oxidized primary OA (OPOA), and aqueous-phase OOA (aq-OOA) (Xu et al., 2018).

cal differences of aerosol optical properties in winter in Beijing. In particular, low ratios $260 \mathrm{~m} /$ ground were frequently observed during cleaning stages of severe haze episodes and nighttime, with strong local emissions and low MLH. The diurnal cycles of ratios $260 \mathrm{~m} /$ ground and $R_{260 \mathrm{~m} / \text { ground }}^{2}$ further indicated that the change of MLH played an important role in driving the vertical differences between daytime and nighttime. Although the vertical difference of SSA was not as much as those of $b_{\text {sca }}$ and $b_{\text {abs }}$, we observed ubiquitously higher values at ground level than $260 \mathrm{~m}$, suggesting relative more scattering aerosols at ground site. A case study further showed complex vertical changes of aerosol optical properties during the formation, evolution, and cleaning stages of the haze episode, which were mainly due to the changes in meteorological conditions (e.g., $T$ inversion), MLH, and source emissions.

The MAC of eBC showed a wide range, from 9.5 to $13.2 \mathrm{~m}^{2} \mathrm{~g}^{-1}$. MAC was observed to increase substantially as a function of $M_{\mathrm{R}}$ during periods with high PM levels, and the increases were closely related with the increases in secondary aerosol species. The positive relationship between MAC and
$\mathrm{O} / \mathrm{C}$ and their diurnal profiles further suggest that photochemical processing can increase MAC by approximately $20 \%$, and up to $40 \%$. It should be noted that the MAC measured in this study could be different from the MAC of ambient aerosol since the particles were dried and sampled at constant room temperature. $\mathrm{BrC}$ was a large contributor to the absorption at $370 \mathrm{~nm}$ in winter, on average accounting for $46 \%$ and $48 \%$ at ground level and $260 \mathrm{~m}$, respectively. By linking with OA factors from PMF analysis, we found that $\mathrm{BrC}$ in winter is predominantly contributed by coal combustion $(48 \%-55 \%)$ followed by biomass burning $(17 \%)$ and photochemical SOA $(\sim 20 \%)$.

Data availability. The data in this study are available from the corresponding author upon request (sunyele@mail.iap.ac.cn).

Supplement. The supplement related to this article is available online at: https://doi.org/10.5194/acp-19-165-2019-supplement.

Author contributions. YS and XC designed the research. CX, WX, JW, QW, DL, WD, JZ, YZ, WZ, TH, and QB conducted the measurements. CX, WX, JW, and DL analyzed the data. GT shared the MLH data. PC supported the PAX instrument. XC and YS wrote the paper. JL, PF, ZW, XG, JA, and $\mathrm{CH}$ reviewed and commented on the paper.

Competing interests. The authors declare that they have no conflict of interest.

Acknowledgements. This work was supported by the National Natural Science Foundation of China (91744207, 41571130034, 41575120) and the National Key Project of Basic Research (2014CB447900). Qingqing Wang acknowledges the support 
from the General Financial Grant from the China Postdoctoral Science Foundation (2017M610972) and the National Postdoctoral Program for Innovative Talents (BX201600157).

Edited by: Chak K. Chan

Reviewed by: two anonymous referees

\section{References}

Bond, T. C., Habib, G., and Bergstrom, R. W.: Limitations in the enhancement of visible light absorption due to mixing state, J. Geophys. Res.-Atmos., 111, D20211, https://doi.org/10.1029/2006jd007315, 2006.

Bond, T. C., Doherty, S. J., Fahey, D. W., Forster, P. M., Berntsen, T., DeAngelo, B. J., Flanner, M. G., Ghan, S., Kärcher, B., Koch, D., Kinne, S., Kondo, Y., Quinn, P. K., Sarofim, M. C., Schultz, M. G., Schulz, M., Venkataraman, C., Zhang, H., Zhang, S., Bellouin, N., Guttikunda, S. K., Hopke, P. K., Jacobson, M. Z., Kaiser, J. W., Klimont, Z., Lohmann, U., Schwarz, J. P., Shindell, D., Storelvmo, T., Warren, S. G., and Zender, C. S.: Bounding the role of black carbon in the climate system: A scientific assessment, J. Geophys. Res., 118, 5380-5552, https://doi.org/10.1002/jgrd.50171, 2013.

Cappa, C. D., Onasch, T. B., Massoli, P., Worsnop, D. R., Bates, T. S., Cross, E. S., Davidovits, P., Hakala, J., Hayden, K. L., Jobson, B. T., Kolesar, K. R., Lack, D. A., Lerner, B. M., Li, S.-M., Mellon, D., Nuaaman, I., Olfert, J. S., Petäjä, T., Quinn, P. K., Song, C., Subramanian, R., Williams, E. J., and Zaveri, R. A.: Radiative Absorption Enhancements Due to the Mixing State of Atmospheric Black Carbon, Science, 337, 1078-1081, https://doi.org/10.1126/science.1223447, 2012.

Chen, C., Sun, Y. L., Xu, W. Q., Du, W., Zhou, L. B., Han, T. T., Wang, Q. Q., Fu, P. Q., Wang, Z. F., Gao, Z. Q., Zhang, Q., and Worsnop, D. R.: Characteristics and sources of submicron aerosols above the urban canopy $(260 \mathrm{~m})$ in Beijing, China, during the 2014 APEC summit, Atmos. Chem. Phys., 15, 1287912895, https://doi.org/10.5194/acp-15-12879-2015, 2015.

Ding, A. J., Huang, X., Nie, W., Sun, J. N., Kerminen, V. M., Petäjä, T., Su, H., Cheng, Y. F., Yang, X. Q., Wang, M. H., Chi, X. G., Wang, J. P., Virkkula, A., Guo, W. D., Yuan, J., Wang, S. Y., Zhang, R. J., Wu, Y. F., Song, Y., Zhu, T., Zilitinkevich, S., Kulmala, M., and Fu, C. B.: Enhanced haze pollution by black carbon in megacities in China, Geophys. Res. Lett., 43, 2873-2879, https://doi.org/10.1002/2016gl067745, 2016.

Drinovec, L., Mocnik, G., Zotter, P., Prévôt, A. S. H., Ruckstuhl, C., Coz, E., Rupakheti, M., Sciare, J., Müller, T., Wiedensohler, A., and Hansen, A. D. A.: The "dual-spot" Aethalometer: an improved measurement of aerosol black carbon with realtime loading compensation, Atmos. Meas. Tech., 8, 1965-1979, https://doi.org/10.5194/amt-8-1965-2015, 2015.

Du, W., Zhao, J., Wang, Y., Zhang, Y., Wang, Q., Xu, W., Chen, C., Han, T., Zhang, F., Li, Z., Fu, P., Li, J., Wang, Z., and Sun, Y.: Simultaneous measurements of particle number size distributions at ground level and $260 \mathrm{~m}$ on a meteorological tower in urban Beijing, China, Atmos. Chem. Phys., 17, 6797-6811, https://doi.org/10.5194/acp-17-6797-2017, 2017.

Du, Z., He, K., Cheng, Y., Duan, F., Ma, Y., Liu, J., Zhang, X., Zheng, M., and Weber, R.: A yearlong study of water-soluble organic carbon in Beijing II: Light absorption properties, Atmos. Environ., 89, 235-241, https://doi.org/10.1016/j.atmosenv.2014.02.022, 2014.

Han, T., Xu, W., Chen, C., Liu, X., Wang, Q., Li, J., Zhao, X., Du, W., Wang, Z., and Sun, Y.: Chemical apportionment of aerosol optical properties during the Asia-Pacific Economic Cooperation summit in Beijing, China, J. Geophys. Res., 120, 12281-212295, https://doi.org/10.1002/2015JD023918, 2015.

Han, T., Xu, W., Li, J., Freedman, A., Zhao, J., Wang, Q., Chen, C., Zhang, Y., Wang, Z., Fu, P., Liu, X., and Sun, Y.: Aerosol Optical Properties Measurements by a CAPS Single Scattering Albedo Monitor: Comparisons between Summer and Winter in Beijing, China, J. Geophys. Res.-Atmos., 122, 2513-2526, https://doi.org/10.1002/2016jd025762, 2017.

Haywood, J. and Boucher, O.: Estimates of the direct and indirect radiative forcing due to tropospheric aerosols: A review, Rev. Geophys., 38, 513-543, https://doi.org/10.1029/1999rg000078, 2000.

Horvath, H.: Experimental calibration for aerosol light absorption measurements using the integrating plate method - Summary of the data, J. Aerosol Sci., 28, 1149-1161, https://doi.org/10.1016/S0021-8502(97)00007-4, 1997.

Kim, D. and Ramanathan, V.: Solar radiation budget and radiative forcing due to aerosols and clouds, J. Geophys. Res., 113, D02203, https://doi.org/10.1029/2007jd008434, 2008.

Lack, D. A., Langridge, J. M., Bahreini, R., Cappa, C. D., Middlebrook, A. M., and Schwarz, J. P.: Brown carbon and internal mixing in biomass burning particles, P. Natl. Acad. Sci. USA, 109, 14802-14807, https://doi.org/10.1073/pnas.1206575109, 2012.

Laskin, A., Laskin, J., and Nizkorodov, S. A.: Chemistry of Atmospheric Brown Carbon, Chem. Rev., 115, 4335-4382, https://doi.org/10.1021/cr5006167, 2015.

Liu, D., Taylor, J. W., Young, D. E., Flynn, M. J., Coe, H., and Allan, J. D.: The effect of complex black carbon microphysics on the determination of the optical properties of brown carbon, Geophys. Res. Lett., 42, 613-619, https://doi.org/10.1002/2014GL062443, 2015.

Liu, D., Whitehead, J., Alfarra, M. R., Reyes-Villegas, E., Spracklen, Dominick V., Reddington, Carly L., Kong, S., Williams, Paul I., Ting, Y.-C., Haslett, S., Taylor, Jonathan W., Flynn, Michael J., Morgan, William T., McFiggans, G., Coe, H., and Allan, James D.: Black-carbon absorption enhancement in the atmosphere determined by particle mixing state, Nat. Geosci., 10, 184-188, https://doi.org/10.1038/ngeo2901, 2017.

Liu, S., Aiken, A. C., Gorkowski, K., Dubey, M. K., Cappa, C. D., Williams, L. R., Herndon, S. C., Massoli, P., Fortner, E. C., Chhabra, P. S., Brooks, W. A., Onasch, T. B., Jayne, J. T., Worsnop, D. R., China, S., Sharma, N., Mazzoleni, C., Xu, L., Ng, N. L., Liu, D., Allan, J. D., Lee, J. D., Fleming, Z. L., Mohr, C., Zotter, P., Szidat, S., and Prevot, A. S.: Enhanced light absorption by mixed source black and brown carbon particles in UK winter, Nat. Commun., 6, 8435, https://doi.org/10.1038/ncomms9435, 2015.

Moschos, V., Kumar, N. K., Daellenbach, K. R., Baltensperger, U., Prévôt, A. S. H., and El Haddad, I.: Source Apportionment of Brown Carbon Absorption by Coupling Ultraviolet-Visible Spectroscopy with Aerosol Mass Spectrometry, Environ. Sci. Tech. Let., 5, 302-308, https://doi.org/10.1021/acs.estlett.8b00118, 2018. 
Onasch, T. B., Trimborn, A., Fortner, E. C., Jayne, J. T., Kok, G. L., Williams, L. R., Davidovits, P., and Worsnop, D. R.: Soot Particle Aerosol Mass Spectrometer: Development, Validation, and Initial Application, Aerosol Sci. Tech., 46, 804-817, https://doi.org/10.1080/02786826.2012.663948, 2012.

Onasch, T. B., Massoli, P., Kebabian, P. L., Hills, F. B., Bacon, F. W., and Freedman, A.: Single Scattering Albedo Monitor for Airborne Particulates, Aerosol Sci. Tech., 49, 267-279, https://doi.org/10.1080/02786826.2015.1022248, 2015.

Peng, J., Hu, M., Guo, S., Du, Z., Zheng, J., Shang, D., Levy, Z. M., Zeng, L., Shao, M., and Wu, Y. S.: Markedly enhanced absorption and direct radiative forcing of black carbon under polluted urban environments, P. Natl. Acad. Sci. USA, 113, 4266-4271, https://doi.org/10.1073/pnas.1602310113, 2016.

Petzold, A., Ogren, J. A., Fiebig, M., Laj, P., Li, S.-M., Baltensperger, U., Holzer-Popp, T., Kinne, S., Pappalardo, G., Sugimoto, N., Wehrli, C., Wiedensohler, A., and Zhang, X.-Y.: Recommendations for reporting "black carbon" measurements, Atmos. Chem. Phys., 13, 8365-8379, https://doi.org/10.5194/acp13-8365-2013, 2013.

Ran, L., Deng, Z. Z., Wang, P. C., and Xia, X. A.: Black carbon and wavelength-dependent aerosol absorption in the North China Plain based on two-year aethalometer measurements, Atmos. Environ., 142, 132-144, https://doi.org/10.1016/j.atmosenv.2016.07.014, 2016.

Rosenfeld, D.: TRMM observed first direct evidence of smoke from forest fires inhibiting rainfall, Geophys. Res. Lett., 26, 31053108, https://doi.org/10.1029/1999g1006066, 1999.

Stocker, T. F., Qin, D., Plattner, G.-K., Tignor, M., Allen, S. K., Boschung, J., Nauels, A., Xia, Y., and Bex, V.: The physical science basis. Contribution of Working Group I to the Fifth Assessment Report of the Intergovernmental Panel on Climate Change, Comp. Geom., 18, 95-123, 2013.

Sun, J., Zhi, G., Hitzenberger, R., Chen, Y., Tian, C., Zhang, Y., Feng, Y., Cheng, M., Zhang, Y., Cai, J., Chen, F., Qiu, Y., Jiang, Z., Li, J., Zhang, G., and Mo, Y.: Emission factors and light absorption properties of brown carbon from household coal combustion in China, Atmos. Chem. Phys., 17, 4769-4780, https://doi.org/10.5194/acp-17-4769-2017, 2017.

Sun, Y., Wang, Z., Fu, P., Jiang, Q., Yang, T., Li, J., and Ge, X.: The impact of relative humidity on aerosol composition and evolution processes during wintertime in Beijing, China, Atmos. Environ., 77, 927-934, https://doi.org/10.1016/j.atmosenv.2013.06.019, 2013.

Sun, Y., Du, W., Wang, Q., Zhang, Q., Chen, C., Chen, Y., Chen, Z., Fu, P., Wang, Z., Gao, Z., and Worsnop, D. R.: Real-Time Characterization of Aerosol Particle Composition above the Urban Canopy in Beijing: Insights into the Interactions between the Atmospheric Boundary Layer and Aerosol Chemistry, Environ. Sci. Technol., 49, 11340-11347, https://doi.org/10.1021/acs.est.5b02373, 2015.

Sun, Y., Wang, Z., Wild, O., Xu, W., Chen, C., Fu, P., Du, W., Zhou, L., Zhang, Q., Han, T., Wang, Q., Pan, X., Zheng, H., Li, J., Guo, X., Liu, J., and Worsnop, D. R.: "APEC Blue": Secondary Aerosol Reductions from Emission Controls in Beijing, Sci. Rep.-UK, 6, 20668, https://doi.org/10.1038/srep20668, 2016.

Sun, Y. L., Jiang, Q., Wang, Z. F., Fu, P. Q., Li, J., Yang, T., and Yin, Y.: Investigation of the sources and evolution processes of severe haze pollution in Beijing in January 2013, J. Geophys. Res., 119, 4380-4398, https://doi.org/10.1002/2014jd021641, 2014.

Tang, G., Zhu, X., Hu, B., Xin, J., Wang, L., Münkel, C., Mao, G., and Wang, Y.: Impact of emission controls on air quality in Beijing during APEC 2014: lidar ceilometer observations, Atmos. Chem. Phys., 15, 12667-12680, https://doi.org/10.5194/acp-1512667-2015, 2015.

Tang, G., Zhang, J., Zhu, X., Song, T., Münkel, C., Hu, B., Schäfer, K., Liu, Z., Zhang, J., Wang, L., Xin, J., Suppan, P., and Wang, Y.: Mixing layer height and its implications for air pollution over Beijing, China, Atmos. Chem. Phys., 16, 2459-2475, https://doi.org/10.5194/acp-16-2459-2016, 2016.

Tao, J., Zhang, L., Gao, J., Wang, H., Chai, F., and Wang, S.: Aerosol chemical composition and light scattering during a winter season in Beijing, Atmos. Environ., 110, 36-44, https://doi.org/10.1016/j.atmosenv.2015.03.037, 2015.

Wang, J., Onasch, T. B., Ge, X., Collier, S., Zhang, Q., Sun, Y., Yu, H., Chen, M., Prévôt, A. S. H., and Worsnop, D. R.: Observation of Fullerene Soot in Eastern China, Environ. Sci. Tech. Let., 3, 121-126, https://doi.org/10.1021/acs.estlett.6b00044, 2016.

Wang, J., Zhang, Q., Chen, M. D., Collier, S., Zhou, S., Ge, X., $\mathrm{Xu}$, J., Shi, J., Xie, C., and Hu, J.: First chemical characterization of refractory black carbon aerosols and associated coatings over the Tibetan Plateau (4730 m a.s.1), Environ. Sci. Technol., 51, 14072-14082, https://doi.org/10.1021/acs.est.7b03973, 2017.

Wang, J., Liu, D., Ge, X., Wu, Y., Shen, F., Chen, M., Zhao, J., Xie, C., Wang, Q., Xu, W., Zhang, J., Hu, J., Allan, J., Joshi, R., $\mathrm{Fu}, \mathrm{P}$., Coe, H., and Sun, Y.: Characterization of black carboncontaining fine particles in Beijing during wintertime, Atmos. Chem. Phys. Discuss., https://doi.org/10.5194/acp-2018-800, in review, 2018.

Wang, Q., Sun, Y., Jiang, Q., Du, W., Sun, C., Fu, P., and Wang, Z.: Chemical composition of aerosol particles and light extinction apportionment before and during heating season in Beijing, China, J. Geophys. Res., 120, 12708-12722, 2015.

Wang, Q., Sun, Y., Xu, W., Du, W., Zhou, L., Tang, G., Chen, C., Cheng, X., Zhao, X., Ji, D., Han, T., Wang, Z., Li, J., and Wang, Z.: Vertically resolved characteristics of air pollution during two severe winter haze episodes in urban Beijing, China, Atmos. Chem. Phys., 18, 2495-2509, https://doi.org/10.5194/acp18-2495-2018, 2018.

Wang, Z., Huang, X., and Ding, A.: Dome effect of black carbon and its key influencing factors: a one-dimensional modelling study, Atmos. Chem. Phys., 18, 2821-2834, https://doi.org/10.5194/acp-18-2821-2018, 2018.

Xu, W. Q., Sun, Y. L., Chen, C., Du, W., Han, T. T., Wang, Q. Q., Fu, P. Q., Wang, Z. F., Zhao, X. J., Zhou, L. B., Ji, D. S., Wang, P. C., and Worsnop, D. R.: Aerosol composition, oxidation properties, and sources in Beijing: results from the 2014 Asia-Pacific Economic Cooperation summit study, Atmos. Chem. Phys., 15, 13681-13698, https://doi.org/10.5194/acp-1513681-2015, 2015.

Xu, W. Q., Sun, Y. L., Wang, Q. Q., Zhao J., Wang, J. F., Ge, X. L., Xie, C. H., Zhou, W., Du, W., Li J., Fu, P. Q., Wang, Z. F., Worsnop, D. R., and Coe, H.: Changes in aerosol chemistry from 2014 to 2016 in winter in Beijing: insights from high resolution aerosol mass spectrometry, J. Geophys. Res.-Atmos, https://doi.org/10.1029/2018JD029245, accepted, 2018. 
Yan, C., Zheng, M., Sullivan, A. P., Bosch, C., Desyaterik, Y., Andersson, A., Li, X., Guo, X., Zhou, T., Gustafsson, Ö., and Collett Jr., J. L.: Chemical characteristics and lightabsorbing property of water-soluble organic carbon in Beijing: Biomass burning contributions, Atmos. Environ., 121, 4-12, https://doi.org/10.1016/j.atmosenv.2015.05.005, 2015.

Yan, C., Zheng, M., Bosch, C., Andersson, A., Desyaterik, Y., Sullivan, A. P., Collett, J. L., Zhao, B., Wang, S., He, K., and Gustafsson, O.: Important fossil source contribution to brown carbon in Beijing during winter, Sci. Rep.-UK, 7, 43182, https://doi.org/10.1038/srep43182, 2017.

Yang, M., Howell, S. G., Zhuang, J., and Huebert, B. J.: Attribution of aerosol light absorption to black carbon, brown carbon, and dust in China - interpretations of atmospheric measurements during EAST-AIRE, Atmos. Chem. Phys., 9, 2035-2050, https://doi.org/10.5194/acp-9-2035-2009, 2009.
Zhao, J., Du, W., Zhang, Y., Wang, Q., Chen, C., Xu, W., Han, T., Wang, Y., Fu, P., Wang, Z., Li, Z., and Sun, Y.: Insights into aerosol chemistry during the 2015 China Victory Day parade: results from simultaneous measurements at ground level and $260 \mathrm{~m}$ in Beijing, Atmos. Chem. Phys., 17, 3215-3232, https://doi.org/10.5194/acp-17-3215-2017, 2017.

Zhou, W., Zhao, J., Ouyang, B., Mehra, A., Xu, W., Wang, Y., Bannan, T. J., Worrall, S. D., Priestley, M., Bacak, A., Chen, Q., Xie, C., Wang, Q., Wang, J., Du, W., Zhang, Y., Ge, X., Ye, P., Lee, J. D., Fu, P., Wang, Z., Worsnop, D., Jones, R., Percival, C. J., Coe, $\mathrm{H}$., and Sun, Y.: Production of $\mathrm{N}_{2} \mathrm{O}_{5}$ and $\mathrm{ClNO}_{2}$ in summer in urban Beijing, China, Atmos. Chem. Phys., 18, 11581-11597, https://doi.org/10.5194/acp-18-11581-2018, 2018. 